Article

\title{
Impact of Plant Growth Regulators to Development of the Second Generation Energy Crop Miscanthus $\times$ giganteus Produced Two Years in Marginal Post-Military Soil
}

\author{
Valentina Pidlisnyuk ${ }^{1}$ (D), Tatyana Stefanovska ${ }^{2}$, Olexander Zhukov ${ }^{3, *}$, Artem Medkow ${ }^{2,4}$, Pavlo Shapoval ${ }^{5}$, \\ Vitalii Stadnik ${ }^{5}$ (D) and Martyn Sozanskyi ${ }^{5}$ (D)
}

check for updates

Citation: Pidlisnyuk, V.; Stefanovska, T.; Zhukov, O.; Medkow, A.; Shapoval, P.; Stadnik, V.; Sozanskyi, M. Impact of Plant Growth Regulators to Development of the Second Generation Energy Crop Miscanthus $\times$ giganteus Produced Two Years in Marginal Post-Military Soil. Appl. Sci. 2022, 12, 881. https:// doi.org/10.3390/app12020881

Academic Editors: Andres Rodriguez-Seijo, Peter Sanderson and Valentina V. Pidlisnyuk

Received: 17 November 2021

Accepted: 11 January 2022

Published: 15 January 2022

Publisher's Note: MDPI stays neutral with regard to jurisdictional claims in published maps and institutional affiliations.

Copyright: (C) 2022 by the authors. Licensee MDPI, Basel, Switzerland. This article is an open access article distributed under the terms and conditions of the Creative Commons Attribution (CC BY) license (https:// creativecommons.org/licenses/by/ $4.0 /)$
1 Department of the Environmental Chemistry and Technology, Jan Evangelista Purkyne University, 40096 Usti nad Labem, Czech Republic; valentyna.pidlisniuk@ujep.cz

2 Department of Entomology, National University of Life and Environmental Sciences, 03041 Kyiv, Ukraine; tstefanovska@nubip.edu.ua (T.S.); a.medkow@gmail.com (A.M.)

3 Department of Botany and Horticulture, Bogdan Khmelnitsky Melitopol State Pedagogical University, 72318 Melitopol, Ukraine

4 State Enterprise Agrobiotech, 02160 Kyiv, Ukraine

5 Department of Physical, Analytical and General Chemistry, Lviv Polytechnic National University, 79013 Lviv, Ukraine; pavlo.y.shapoval@lpnu.ua (P.S.); vitalii.y.stadnik@lpnu.ua (V.S.); martyn.a.sozanskyi@lpnu.ua (M.S.)

* Correspondence: zhukov_dnipro@ukr.net

\begin{abstract}
The impact of the plant growth regulators (PGRs) Stimpo, Regoplant, and Charkor on the production of the second-generation energy crop Miscanthus $\times$ giganteus on marginal post-military soil was investigated during two vegetation seasons. The land, previously a tank training polygon, has not been in use since 1990 and has become marginal. Biological parameters (stem, shoot, and root lengths) and dry biomass values were evaluated in relation to the applied treatments. The multivariate general linear model (M-GLM) results showed a positive influence of Charkor on $M . \times$ giganteus development; the effect was markedly higher in the second year of vegetation. The impact of Stimpo and Regoplant was less noticeable; nevertheless, certain combinations of treatments showed satisfactory results. The M-GLM approach detected the inter-influence of the main factors of the production process, i.e., PGRs, soil, and year of growing. The results showed the predominant influence of year, PGRs and combined factor PGRs $\times$ year on the biological parameters; the other studied factors and their combinations were not as effective. Further research should focus on verifying the field-scale results for the $M . \times$ giganteus plantation established in a post-military area and compare the lab and field studies.
\end{abstract}

Keywords: Miscanthus $\times$ giganteus; multivariate general linear models; plant growth regulators; biological parameters

\section{Introduction}

Plant growth regulators (PGRs) are organic chemical compounds that modify or regulate physiological processes in plants when applied in small concentrations and appreciable measures. These substances include plant hormones (natural or synthetic) and non-nutrient chemicals that do not naturally occur in plants. PGRs are used to influence plant growth and development and better realize their genetic potential [1]. The type and working concentration of PGRs in the liquids applied depend on the plant species, the tissue or organ cultured, and the objective. These substances can influence plant physiology to change morphological (i.e., root biomass and architecture) and metabolic properties [2,3]. The commonly used PGRs are auxins, cytokinins, and gibberellins; some PGRs have as active ingredients biologically active substances synthesized by microorganisms, including fungi, such as micromycetes [3] or species of the genus Cylindrocarpon obtusiusculum Sacc. [4]. 
The fungi are frequently isolated from deciduous and coniferous forests as saprophytes and are highly competitive. Fungi species synthesize common PGRs, cytokinins, gibberellins, and indoleacetic acid [5]. PGRs are one of the active metabolites of fungi; micromycetes have been produced commercially and used to enhance the production of corn, barley, and vegetables in Germany, Eurasian countries, and China [6]. It was illustrated [7-10] that the application of PGRs belonging to this group (Stimpo, Regoplant, Charkor) in the production of corn and barley improved crop yield, mitigated the adverse effects of moisture stress and nutrient limitation, and enhanced tolerance to parasites.

Miscanthus $\times$ giganteus Greef \& Deuter ex Hodkinson \& Renvoize is an industrial crop with a beneficial environmental profile; this perennial grass has a high tolerance to abiotic stresses, is able to grow on marginal land, and has limited nutrient requirements [11]. The plant is seed-sterile, has a C4 profile, and can be utilized in poor soil for boosting soil health [12]. The growing demand for alternative energy and lignocellulose biomass to mitigate climate change has made $M . \times$ giganteus a popular crop [13], and commercial production has been initiated in countries with limited access to energy, including Ukraine $[13,14]$. The crop can be applied as a phytoagent in land slightly contaminated by trace elements (TEs) [15] or oil products [16,17]. Its biomass can be converted to liquid fuels and numerous value-added bio-based products, for example, fibers for fibrous and isolation materials $[18,19]$ and pulp for paper and packaging materials [20,21]. Crop waste can be processed into biochar, which may be returned to the soil as an amendment to improve plant growth $[21,22]$. However, rather often, the harvest value of $M . \times$ giganteus biomass grown on marginal land is not sufficient for commercial exploitation [23] and improvements to the production cycle and different agronomic factors, similar to other crops [24], have been proposed [25,26], including the exploitation of PGRs [27].

The effects of different basal media and their combinations, PGRs, on callus induction and plant regeneration have been studied [28]. Adding a PGR (benzyladenine, a synthetic cytokinin) to nutrient media for the microclonal propagation of $M . \times$ giganteus produced a highly embryogenic callus, which determined the completeness of shoots and accelerated the regeneration of the plant [28]. Supplementing Murashige and Skoog (MS) medium with $0.5 \mathrm{mg} \mathrm{L}^{-1}$ 6-benzyladenine and $0.05 \mathrm{mg} \mathrm{L}^{-1} \alpha$-naphthalene acetic acid in the in vitro cultivation of Miscanthus sacchariflorus L. had a positive effect on adventitious shoot proliferation [29]. A new, effective, and simple regeneration system for Miscanthus sinensis Anders, $M . \times$ giganteus, and M. sacchariflorus was developed, comprising two media supplemented exclusively with growth regulators $\left(5.0 \mathrm{mg} / \mathrm{L}\right.$ of $2,4-\mathrm{D}$ and $0.5 \mathrm{mg} \mathrm{L}^{-1}$ of benzyl adenine, $0.5 \mathrm{mg} \mathrm{L}^{-1}$ of KIN and $0.5 \mathrm{mg} \mathrm{L}^{-1}$ of naphthalene acetic acid) and lasting five months [30].

The impact of PGRs on Miscanthus spp. production was mainly investigated when the plant was cultivated on regular fertile land; however, the reported results are sometimes controversial. Padhye and Groninger [31] found that while two foliar sprays of benzyl adenine at 500 or $1000 \mathrm{mg} \mathrm{L}^{-1}$, trinexapac-ethyl at $220 \mathrm{mg} \mathrm{L}^{-1}$, or uniconazole at $20-40 \mathrm{mg} \mathrm{L}^{-1}$ two weeks apart controlled the height of $M$. sinensis, the benzyladenine application did not suppress the height of this plant, though it did suppress the height of the other tested ornamental grasses. At the same time, the application of trinexapac-ethyl effectively controlled the height of Poaceae grasses, including M. sinensis, but did not influence the tiller number of any plant studied. Application of PGRs based on humic acid showed a significant increase in aboveground and underground $M . \times$ giganteus biomass when the crop was cultivated in fertile soil [32]. At the same time, Hellios et al. [33] found that the use of gibberellic acid and $\mathrm{AB}$ aqua rooting agent, or these two substances together, did not positively affect the rooting of $M . \times$ giganteus seedlings. Laboratory studies related to the effects and interactions between symbiotic fungi, represented by arbuscular mycorrhizal fungi (AMF), along with the endophyte and cytokinin-like growth regulator thidiazuron (TDZ), on M. $\times$ giganteus production indicated [34] that the fungal inoculants and TDZ did not influence plant growth. However, they did modulate phytohormone levels in the leaves. The study highlighted the existence of phytohormone homeostasis under the combined influence of beneficial inoculants and a growth regulator. In greenhouse 
and field experiments, the enhancement of $M . \times$ giganteus productivity with beneficial soil microbes and Ascophyllum nodosum L. seaweed extract was observed on poor-quality, marginal land [25], which may be associated with increased access to limited soil nutrients due to PGR application.

The PGRs emistim, Agrostimulin, and Regoplant, which are based on aversectine and phytohormones produced by Cylindrocarpon obtusiusculum, were tested on $M . \times$ giganteus cultivation in fertile soil [27] and positively impacted the physiological parameters. They increased the value of the chlorophyll ratio, particularly in the early stages of vegetation growth, and enhanced morphometric indicators of plant height, the numbers of stems in the bush, and aboveground biomass yield. In addition, the application of PGRs reduced the dependence of survival rate on weather conditions, which was particularly evident for the late planting time.

A limited number of studies analyzed the impact of PGRs on Miscanthus spp. development in contaminated or marginal lands, including post-military areas. In one study, treatment of $M . \times$. giganteus rhizomes with the humic-based PGRs Gumifild Forte and Fulbital increased plant survival rates when a crop was cultivated in field conditions in previously oil-contaminated soil [35]. The application of PGRs stimulated the development of the root system, improved aboveground biomass, and increased the content of photosynthetic pigments in the leaves. Our previous study, in which Regoplant and Stimpo were tested during one vegetation year of $M . \times$ giganteus in soil slightly contaminated with TEs, indicated the effect of PGR utilization on morphological indicators and biomass parameters when the crop was produced in soil of moderate quality [36]. The influence was greatest when PGRs were combined to treat rhizomes before planting and used in plantation spraying during vegetation [36]. However, the research illustrated that the application of PGRs were not effective when the crop was cultivated in pure nutrients and organic matter soil.

Miscanthus spp. is a perennial grass, and the first two production cycles are the most important for establishing a good stable feedstock [37]. In this regard, PGR influence must be monitored in at least two growing processes. In the previous study [36], it was concluded that the development of plants in pure soil was not sensitive to the application of PGRs; however, the conclusion was based on simple graphical analysis, while the influence of multi-factor interactions, i.e., soil-PGRs, soil-years of cultivation, PGRs-years of cultivation was not statistically evaluated. To overcome this gap, the current research was designed to examine the influence of PGRs on $M . \times$ giganteus cultivation during two vegetation seasons with a statistical evaluation of the primary process factors: soil, time, and PGR type.

Consequently, the goals of the current study were as follows:

- To test the impact of three commonly used PGRs applied in the Miscanthus spp. production scheme, i.e., Regoplant, Stimpo, and Charkor, on dry biomass value during two vegetation seasons;

- To analyze the impact and value of three main factors involved in the production cycle: soil, PGRs, and year of cultivation on plant development.

\section{Materials and Methods}

\subsection{Soil Characteristics}

The laboratory study was carried out in 2017-2018 with soil taken from the postmilitary site in Dolyna, Ivano-Frankivsk Region, Ukraine. This field was not under exploitation since 1991 and was previously used as a tank training polygon of the former Soviet Union army; currently, this land can be considered as marginal post-military area [38]. The physicochemical characteristics of the studied soil were presented and discussed in detail earlier [36]. The field consists of two plots; each plot has a size of $161 \mathrm{~m}^{2}$. The GPS coordinates are: Plot \#1, 48 $58^{\prime} 05.1^{\prime \prime} \mathrm{N}$ and $23^{\circ} 59^{\prime} 41.6^{\prime \prime} \mathrm{E}$; Plot \#2, 48 $58^{\prime} 01.4^{\prime \prime} \mathrm{N}$ and $23^{\circ} 59^{\prime} 33.3^{\prime \prime}$ E. The soil sampling was conducted using the standard approach [39] from one $5 \mathrm{~m} \times 5 \mathrm{~m}$ testing square. The collected soil was first dried to constant weight and then passed through a sieve with a pore diameter of $2 \mathrm{~mm}$ [40] to remove the plant materials and 
stones, followed by thorough mixing. Soil collected for research from Plot \#1 was named Soil I; soil collected from Plot \#2 was named Soil II.

The agrochemical parameters of the research soils determined by standard methods are presented in Table 1. The physicochemical characteristics of the studied soil were presented and discussed in detail previously [36].

Table 1. Agrochemical characteristics of Soil I and Soil II.

\begin{tabular}{|c|c|c|c|c|c|}
\hline Parameter & Soil I & Soil II & Standard & Method & Apparatus \\
\hline $\mathrm{pH}$ & 7.1 & 6.1 & DSTU ISO 10390:2001 [41] & $\mathrm{pH}(\mathrm{KCl})[41]$ & pH meter pH-150МИ \\
\hline Available $\mathrm{P}, \mathrm{mg} \mathrm{kg}^{-1}$ & 50 & 20 & DSTU 4115:2002 [42] & Chirikov [42] & ULAB 102UV \\
\hline Available K, $\mathrm{mg} \mathrm{kg}^{-1}$ & 58 & 73 & DSTU 4115:2002 [42] & Chirikov [42] & Flame photometerCL-378 (ELICO) \\
\hline $\begin{array}{l}\text { Available Ca, mmol-equivalent } \\
\qquad 100 \mathrm{~g}^{-1}\end{array}$ & 17.1 & 15.6 & DSTU 7861:2015 [43] & CINAO [43] & $\begin{array}{c}\text { Titration method (chemical beaker, magnetic stirrer, } \\
\text { pipettes) }\end{array}$ \\
\hline $\begin{array}{c}\text { Available } \mathrm{Mg}, \\
\text { mmol-equivalent } 100 \mathrm{~g}^{-1}\end{array}$ & 1.5 & 1.9 & DSTU 7861:2015 [43] & CINAO [43] & $\begin{array}{l}\text { Titration method (chemical beaker, magnetic stirrer, } \\
\text { pipettes) }\end{array}$ \\
\hline $\begin{array}{l}\text { Alkaline hydrolyzed } \mathrm{N}, \mathrm{mg} \\
\mathrm{kg}^{-1}\end{array}$ & 120 & 130 & DSTU 7863:2015 [44] & Cornfield [44] & $\begin{array}{l}\text { Titration method (chemical beaker, magnetic stirrer, } \\
\text { pipettes) }\end{array}$ \\
\hline Available S, $\mathrm{mg} \mathrm{kg}^{-1}$ & 0.2 & 0.1 & DSTU 8347:2015 [45] & Sokolovsky [45] & ULAB 102UV (ULAB) \\
\hline Organic matter, \% & 11.2 & 10.9 & DSTU 7632:2014 [46] & Tyurin [46] & ULAB 102UV (ULAB) \\
\hline
\end{tabular}

Before setting up the PGR experiment, the particle size distribution of the soils was determined following [47]. The results are presented in Table 2.

Table 2. Soils Fractions *

\begin{tabular}{|c|c|c|c|c|c|c|c|c|}
\hline \multirow{4}{*}{ Soil } & \multirow{4}{*}{$\begin{array}{l}\text { Hygroscopic } \\
\text { Moisture, \% }\end{array}$} & \multicolumn{6}{|c|}{ Soil Fractions (in mm), Content (in \%) } & \multirow{4}{*}{$\begin{array}{c}\text { Sum of } \\
\text { Particles } \\
\text { Less than } \\
0.01 \mathrm{~mm} \%\end{array}$} \\
\hline & & \multirow{2}{*}{\multicolumn{2}{|c|}{$\begin{array}{l}\text { Physical Sand } \\
\text { Sand }\end{array}$}} & & \multicolumn{3}{|c|}{ Physical Clay $(<0.01)$} & \\
\hline & & & & \multicolumn{3}{|c|}{ Silt } & \multirow{2}{*}{$\begin{array}{c}\text { Clay } \\
<0.001\end{array}$} & \\
\hline & & $1.00-0.25$ & $0.25-0.05$ & $0.05-0.01$ & $0.01-0.005$ & $0.005-0.001$ & & \\
\hline $\mathrm{I}$ & 3.52 & 0.94 & 4.55 & 22.24 & 5.56 & 22.93 & 43.78 & 72.28 \\
\hline II & 3.08 & 2.57 & 2.94 & 29.18 & 6.95 & 16.68 & 41.69 & 65.31 \\
\hline
\end{tabular}

* Standard: DSTU 4730:2007 [47]

\subsection{Design of the Pot Experiment and Characteristics of PGRs}

The laboratory experiments were performed in greenhouse conditions in pots. First, $1 \mathrm{~kg}$ of sand and $1 \mathrm{~kg}$ of expanded clay for drainage were placed in the bottom of each pot, followed by $10 \mathrm{~kg}$ of the collected soil. The planting material was M. $\times$. giganteus J.M. Greef \& Deuter ex Hodkinson \& Renvoize (Angiospermae: Poaceae), and the rhizomes of the variety "Rankova Zorya" were three years old and had an average weight of $20 \pm 2 \mathrm{~g}$. The planting materials were obtained from the nursery of the Institute of Sugar Beets and Bioenergy Crops, Ukraine, Kyiv. Two rhizomes were planted in each pot to a depth of $10 \mathrm{~cm}$. Then, the experiment plan in space was performed according to the Latin square [48]; each of the experiments was repeated in three replications. Three PGRs, Stimpo, Regoplant, and Charkor, were utilized to treat planting materials before the experiment and during vegetation.

Charkor belongs to toxicity class IV, the lowest under the standard [49]; LD50 related to mice and rats is $5300 \mathrm{mg} \mathrm{kg}^{-1}$. The active substance is a complex of 2,6-dimethylpiridin1-oxide with $\mathrm{C}_{12} \mathrm{H}_{10} \mathrm{O}_{2}$-naphtylacethic acid. The complex of the substances formed the active component of emistim $\mathrm{C}$ with the natural background phytohormones of aucsine, citokininon nature, saturated and unsaturated fatty acids, amino acids, carbohydrates, and biogenic ion microelements. Charkor does not have cumulative properties and is not accumulated in soil and produced crops. It is a slightly yellow, homogenous, transparent liquid, easily dissolved in water, acetone, ethyl alcohol, and other organic solvents.

Regoplant is a substance belonging to toxicity class IV [49]; LD50 related to mice and rats is $5800 \mathrm{mg} \mathrm{kg}^{-1}$. The active substance is a complex of physiologically active compounds: metabolic products of the micromycetic fungi Cylindrocarpon obtusiusculum, a modified compound of PGR; emistim C, a complex of biogenic microelements; and 
aversectin C, a metabolic product of actymonycetic fungi Streptomyces avermytilis. This product does not have cumulative properties and is not accumulated in soil and produced crops. Regoplant is a homogeneous, light green, transparent liquid that can be indifferently dissolved in water, acetone, ethyl alcohol, and other organic solvents.

Stimpo is a substance belonging to toxicity class IV [49]; LD50 related to mice and rats is $5800 \mathrm{mg} \mathrm{kg}^{-1}$. It is formed of a complex of physiologically active compounds: metabolic products of the micromycetic fungi Cylindrocarpon obtusiusculum, a modified compound of PGR; emistim C, a complex of biogenic microelements; and aversectin C, a metabolic product of the actymonycetic fungi Streptomyces avermytilis. The substance does not have cumulative properties and is not accumulated in soil and produced crops during application. Stimpo is a homogeneous, colorless, transparent liquid easily dissolved in water, acetone, ethyl alcohol, and other organic solvents.

All three selected PGRs were produced by the Inter-institutional Scientific and Technological Centre "Agrobiotech" (Agrobiotech) under the jurisdiction of the National Academy of Science and Ministry of Education, Ukraine (ISTC NAS\&MOE), (https: / / www.agrobiotech.com.ua, accessed on 24 December 2021). The substances are produced on an industrial scale, however, the producer does not provide detailed formulations [50]. Publicly available characteristics of selected PGRs are presented in Table 3.

Table 3. Characteristics of PGRs used for the treatment of $M . \times$ giganteus (adapted from [16,36] and http:/ / www.agrobiotech.com.ua, accessed on 10 November 2021).

\begin{tabular}{|c|c|c|c|}
\hline PGR Title & Stimpo & Regoplant & Charkor \\
\hline Standard & $\begin{array}{c}\text { TU U 20.2-31168762-005:2012 } \\
{[51]}\end{array}$ & $\begin{array}{c}\text { TU U 20.2-31168762-006:2012 } \\
\text { [52] }\end{array}$ & $\begin{array}{c}\text { TU U 24.2-03563790-041-2001 } \\
\text { [53] }\end{array}$ \\
\hline Content & Natural & Natural & Synthetic \\
\hline Mode of action & $\begin{array}{l}\text { Promotes accelerated cell } \\
\text { division and the development } \\
\text { of a powerful root system, } \\
\text { increases the leaf area and } \\
\text { chlorophyll content, reduces } \\
\text { phytotoxic action of pesticides, } \\
\text { enhances host plant tolerance to } \\
\text { pathogenic organisms }\end{array}$ & $\begin{array}{l}\text { Promotes accelerated cell } \\
\text { division, rhyzogenesis, } \\
\text { development of } \\
\text { symbiotic microflora in the root } \\
\text { system, intensification of } \\
\text { photosynthetic activity and } \\
\text { development of leaf surface, } \\
\text { decrease in phytotoxic action of } \\
\text { pesticides, enhances host plant } \\
\text { tolerance to pathogenic } \\
\text { organisms }\end{array}$ & $\begin{array}{l}\text { Accelerates cell division, } \\
\text { rhizogenesis, development of } \\
\text { symbiotic microflora in the root } \\
\text { system, enhances } \\
\text { photosynthetic activity and } \\
\text { development of the leaf } \\
\text { surface. High-performance } \\
\text { stimulant of root formation. } \\
\text { Increases plant resistance to } \\
\text { abiotic stress }\end{array}$ \\
\hline \multirow[t]{2}{*}{ Composition } & $\begin{array}{c}\text { PGR emistim C: emistim C: } \\
\text { metabolic product of } \\
\text { Cylindrocarpon } \\
\text { obtusiusculum-analogues of } \\
\text { phytohormones of auxin, } \\
\text { cytokinin nature, saturated and } \\
\text { unsaturated fatty acids, amino } \\
\text { acids, carbohydrates }\end{array}$ & $\begin{array}{c}\text { PGR emistim C: emistim C: } \\
\text { metabolic product of } \\
\text { Cylindrocarpon } \\
\text { obtusiusculum - analogues of } \\
\text { phytohormones of auxin, } \\
\text { cytokinin nature, saturated and } \\
\text { unsaturated fatty acids, amino } \\
\text { acids, } \\
\text { carbohydrates }\end{array}$ & $\begin{array}{c}\text { PGR emistim C: emistim C: } \\
\text { metabolic product of } \\
\text { Cylindrocarpon } \\
\text { obtusiusculum-analogues of } \\
\text { phytohormones of auxin, } \\
\text { cytokinin nature, saturated and } \\
\text { unsaturated fatty acids, amino } \\
\text { acids, carbohydrates }\end{array}$ \\
\hline & $\begin{array}{l}\text { Natural complex aversectin C, } \\
\text { a metabolic product of } \\
\text { actinomycetes Streptomyces } \\
\text { avermytilis. Microelements: } \\
\text { boric acid, copper sulphuric } \\
\text { acid (II) 5-water, ammonium, } \\
\text { molybdenum acid, manganese } \\
\text { (II) chloride 4-water, } \\
\text { potassium iodide }\end{array}$ & $\begin{array}{c}\text { Natural complex aversectin } \mathrm{C} \text {, } \\
\text { a metabolic product of } \\
\text { actinomycetes } \\
\text { Streptomyces avermytilis. } \\
\text { Universal micro fertilizer } \\
\text { "Reakom-ZERNO": } \\
\text { Composition of biogenic } \\
\text { microelements }\end{array}$ & $\begin{array}{l}\text { 2,6-Dimethylpyridine-N- } \\
\text { oxide with a synthetic analogue } \\
\text { of phytohormone with } \\
\text { 1-naphthyl-acetic acid. } \\
\text { Empirical formula } \mathrm{C}_{19} \mathrm{H}_{19} \mathrm{NO}_{3} \text {. } \\
\text { Structural formula: }\end{array}$ \\
\hline
\end{tabular}


Charkor, Regoplant and Stimpo are widely utilized in Ukraine and surrounding countries for improving the development and biomass production of different agricultural plants, including first-generation energy crops: barley, wheat, sugar beet, fruits, and vegetables [6-8,50]. Recently, Stimpo and Regoplant obtained Organic Standard certification and can be used in organic agriculture [54]. The type of $M . \times$ giganteus treatment with selected PGRs was chosen based on their function type [6,9,51-53,55]. The composition of Charkor includes chemically synthesized analogues of phytohormones, i.e., 2,6-Dimethylpyridine$\mathrm{N}$-oxide and 1-naphthylacetic acid; these substances are plant root initiators/ stimulators. Charkor was successfully utilized when green and woody cutting seedlings of fruit and ornamental trees, shrubs, flowers, and medicinal plants were treated. Hence, Charkor's standard application method involves the soaking of vegetative plant parts in a water solution of this substance before planting; spraying biomass during vegetation is not utilized in the case of Charkor. The recommended concentration (Table 3) of Charkor in the water solution used to treat vegetative parts before planting is between $0.1 \%$ and $4 \%$; the recommended exposition time is between 2 and $20 \mathrm{~h}$. Following these recommendations, $M . \times$ giganteus rhizomes were soaked in a Charkor water solution with concentrations of $0.1 \%$ and $0.4 \%$ and an exposure time of $12 \mathrm{~h}$. In the control experiment, rhizomes were soaked in distilled water without PGR at the same exposition time. Regoplant and Stimpo do not have chemically synthesized analogues of plant hormones and, unlike Charkor, they are not characterized with a strong root initiation effect. Based on testing with wheat and barley (which belong to the same family, Poaceae, as $M . \times$ giganteus), these PGRs are recommended $[6,55]$ for utilization in a combined treatment, i.e., treatment of planting material before planting followed by spraying of the vegetation: it is recommended to perform the the first spray when three to four pairs of leaves have appeared, and the second when six pairs have appeared. For Regoplant, the proposed treatment dose is between $1.22-2.44 \%$ with an exposition of $2-24 \mathrm{~h}$. In the current study, we used a $2.44 \%$ water solution of Regoplant to treat rhizomes before planting and $1.22 \%$ and $2.44 \%$ water solutions for spraying, with an exposure time of $12 \mathrm{~h}$. In the control experiment, rhizomes were soaked in distilled water without PGR at the same exposition time or sprayed with distilled water. For Stimpo, the proposed treatment dose for the initial planting material is between $0.25-0.50 \%$ with an exposition of $2-24 \mathrm{~h}$. In the current study, we used a $0.25 \%$ water solution of Stimpo to treat rhizomes before planting and $0.25 \%$ and $0.50 \%$ water solutions for spraying with an exposure time of $12 \mathrm{~h}$. In the control experiment, rhizomes were soaked in distilled water without PGR at the same exposition time or sprayed with distilled water.

The following abbreviations are used relating to the treatment of $M . \times$ giganteus by PGRs: Ch1: $0.1 \%$ concentration of Charkor treatment of rhizomes before planting; Ch2: $0.4 \%$ Charkor treatment of rhizomes before planting; R1: $2.44 \%$ Regoplant treatment of rhizomes before planting; R2: $2.44 \%$ Regoplant treatment of rhizomes before planting and $1.22 \%$ Regoplant spraying; R3: $2.44 \%$ Regoplant treatment of rhizomes before planting and 2.44\% Regoplant spraying; S1: $0.25 \%$ Stimpo treatment of rhizomes before planting and 0.1\% Stimpo spraying; S2: 0.25\% Stimpo treatment of rhizomes before planting and $0.25 \%$ Stimpo spraying; S3: $0.25 \%$ Stimpo treatment of rhizomes before planting and $0.5 \%$ Stimpo spraying; W: control, treatment with water.

The study was started on 11 May 2017 and completed on 10 October 2018. Plants were watered with tap water two to three times a week during both vegetation seasons. After harvest on 13 October 2017, the pots containing the roots of the plants were stored in the dark over winter. On 30 April 2018, the experiment re-started when the first green shoots appeared, and the pots were returned to the light in the greenhouse.

\subsection{Measuring of Biological Parameters and Dry Biomass Value}

Biological parameters: stem length, stem number, and shoots were monitored over vegetation. At the end of each vegetation when the leaves turned yellow the final measurements of stem length, number of stems, number of shoots, and root length were made. 
The cut aboveground biomass was dried on an open surface till the contact weight. Further, in order to determine the dry biomass value (DW), a certain amount of biomass was transferred to the metal box and dried in a thermostat at $100-105^{\circ} \mathrm{C}$ to the constant weight. Initially, biomass was dried for eight hours, then, it was weighed and put in the oven again; the procedure was repeated until the difference between the two weights was less than $0.0001 \mathrm{~g}$.

\subsection{Statistical Analysis}

The results were evaluated using multivariate general linear models (M-GLMs) using the Statistics v. 12.0 PL software package from TIBCO Software, Inc. (Palo Alto, CA, USA) [56]. Two multivariate GLMs were performed, and the following factors were considered: the Effect (PGR type and control (nine levels)), Soil (Soil I and Soil II), and Year (two levels). Year $\times$ Soil, Year $\times$ Effect, Soil $\times$ Effect, Year $\times$ Soil $\times$ Effect (interaction) were used as categorical predictors to explain $M . \times$ giganteus trait variations, i.e., number of stems, number of shoots, length of roots, and length of stems. The differences between individual treatments were tested using a planned comparison.

\section{Results and Discussion}

The lignocellulose biomass, which contains carbohydrate polymers (cellulose and hemicellulose) and an aromatic polymer (lignin), is identified as a prospective alternative for biofuel production [19-21]. The conversion of lignocellulose biomass to heat, bio-oil, syngas, ethanol, methane, and hydrogen is valuable in climate change mitigation [57]. The biomass of second-generation industrial crops, including Miscanthus spp., can be processed to produce energy through the thermochemical routes of gasification and pyrolysis [58]. The effectiveness of the processes is determined by the operational conditions of feed properties, oxidizer, temperature, heating rate, and residence time [21]. Efforts are focused on utilizing different agricultural factors to ensure the proper development of plants and deriving an economically valuable amount of biomass [12,59]. These goals can be achieved with the application of soil amendments, such as sludge $[23,26,60]$, carbon contented amendments [61], fertilizers [62], and by influencing the initial planting materials with PGRs [27,32,36] or microbial isolates [63]. The harvest value of Miscanthus spp. biomass is determined by plant development during vegetation [64] and plant stress [16], which can be evaluated by measuring the common biological indicators: plant health, number of stems, number of shoots, and dry biomass at harvest.

According to the analysis (Tables 1 and 2), Soil I is slightly neutral, while Soil II is acidic. Both soils are weak in phosphorus and rich enough in potassium. Sulfur content is low in both soils, and both soils have high organic matter values. Based on the standard evaluation [65], the researched soils included enough nutrients; however, Soil I is less acceptable for agricultural purposes due to its higher swelling and shrinking characteristics, which implies a higher content of clay (Table 2) [65,66] and, following Jones et al. [67], led to worst plant develop in this soil. Based on soil properties (Tables 1 and 2), the differences in the influence of PGR treatment on the $M . \times$ giganteus production cycle may be expected.

The influence of PGR treatments was more pronounced in the second year of vegetation than in the first year (Figure 1). For the second vegetation year, the differences in impact on the bioparameters depending on soil type are more prominent with the plants grown in Soil II compared to those grown in Soil I. This may be due to the slightly better quality of Soil II in terms of $\mathrm{pH}$ value and swelling and shrinking characteristics (Tables 1 and 2). The impact of the studied factors, i.e.: PGRs, soil type (Soil I and Soil II), and time (year of vegetation), on M. $\times$ giganteus bioparameters are presented in Tables 4 and S1, Figures S1-S4 (Supplementary Materials). These studied factors explained $66-94 \%$ of the variation of the traits and were statistically significantly influenced to the number of stems (Table 4). 


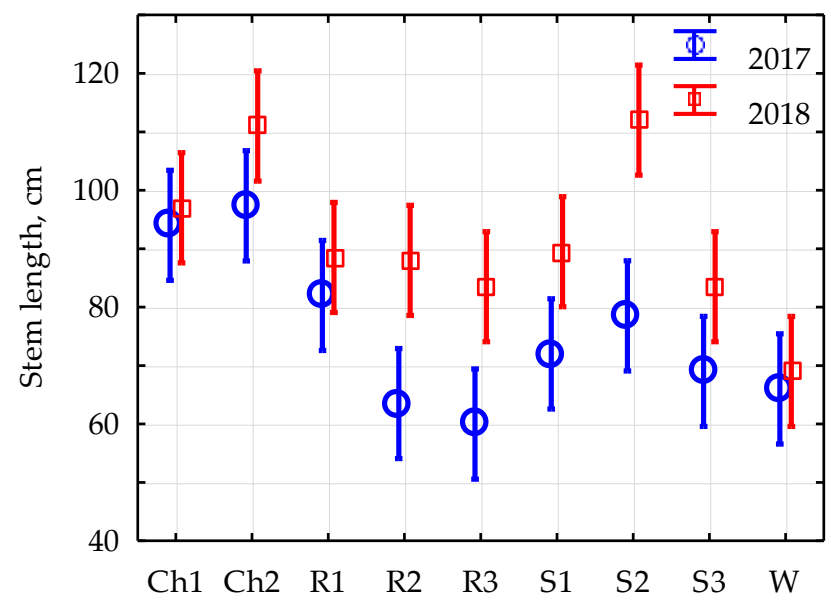

(a)

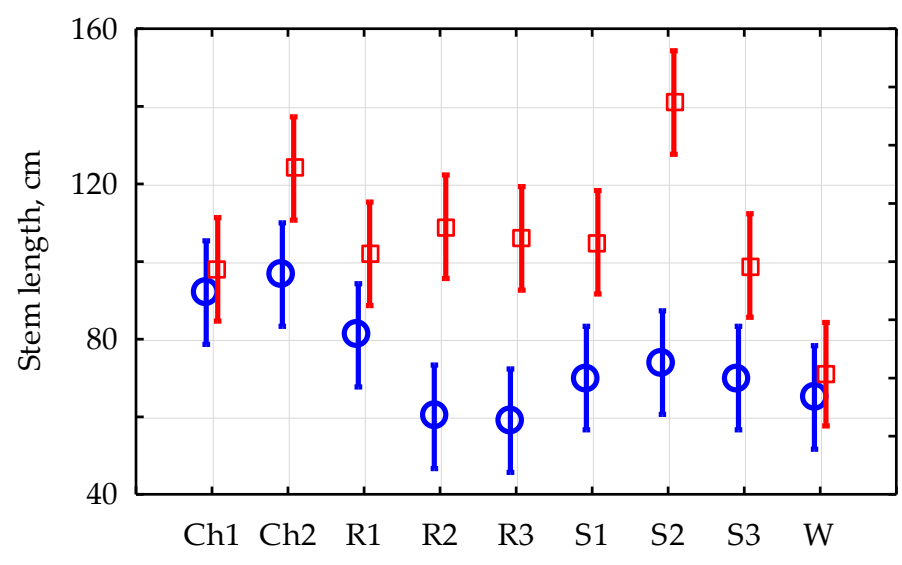

Soil type I

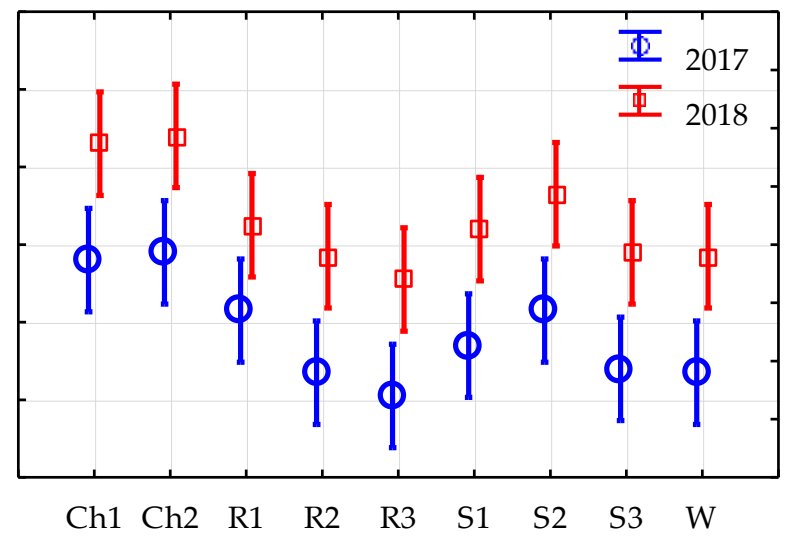

Soil type II

(b)

Figure 1. The impact of the various treatments of PGRs on stem length (a) depending on the soil type (b). Squares and circles show least-squares means. Vertical bars denote 0.95 confidence intervals.

Table 4. Evaluation of the effect of the research factors, PGRs, soil type, and year of vegetation, on M. $\times$ giganteus bioparameters following M-GLM procedures.

\begin{tabular}{|c|c|c|c|c|c|c|c|c|}
\hline \multirow[t]{2}{*}{ Factor } & \multicolumn{2}{|c|}{$\begin{array}{c}\text { Number of Stems, } \\
R_{a d j}{ }^{2}=0.78 \\
F=15.35, p<0.001\end{array}$} & \multicolumn{2}{|c|}{$\begin{array}{c}\text { Number of Shoots, } \\
R_{a d j}{ }^{2}=0.66 \\
F=6.87, p<0.001\end{array}$} & \multicolumn{2}{|c|}{$\begin{array}{c}\text { Length of Roots, } \\
R_{a d j}^{2}=0.94 \\
F=45.46, p<0.001\end{array}$} & \multicolumn{2}{|c|}{$\begin{array}{c}\text { Length of Stems, cm, } \\
R_{a d j}^{2}=0.71 \\
F=8.49, p<0.001\end{array}$} \\
\hline & F-Ratio & $p$-Level & F-Ratio & $p$-Level & F-Ratio & $p$-Level & F-Ratio & $p$-Level \\
\hline Year & 254.22 & $<0.001$ & 79.61 & $<0.001$ & 479.91 & $<0.001$ & 48.50 & $<0.001$ \\
\hline Soil & 46.69 & $<0.001$ & 1.29 & 0.26 & 31.05 & $<0.001$ & 34.82 & $<0.001$ \\
\hline PGR & 4.11 & $<0.001$ & 14.55 & $<0.001$ & 102.06 & $<0.001$ & 13.72 & $<0.001$ \\
\hline Year $\times$ Soil & 48.86 & $<0.001$ & 0.03 & 0.87 & 13.48 & $<0.001$ & 54.22 & $<0.001$ \\
\hline Year $\times$ PGR & 3.54 & $<0.001$ & 2.87 & $<0.001$ & 29.27 & $<0.001$ & 2.44 & 0.02 \\
\hline Soil × PGR & 0.44 & 0.89 & 0.93 & 0.49 & 1.19 & 0.32 & 1.62 & 0.14 \\
\hline Year $\times$ Soil $\times$ PGR & 0.37 & 0.93 & 1.57 & 0.15 & 0.83 & 0.58 & 2.19 & 0.04 \\
\hline
\end{tabular}

The stronger influence of PGR treatment in the second year of $M . \times$ giganteus vegetation (Figures S1-S4) may explain the reduction in PGR impact when the plant grew in the pure quality soil [36] because results were obtained only for one vegetation of M. $\times$ giganteus. 
The treatment with various PGRs impacted $M . \times$ giganteus biological parameters differently. For example, while $\mathrm{Ch} 1, \mathrm{Ch} 2$, and S2 treatments increased the number of stems (Figure 1a), R2, R3, and Ch2 treatments impacted mainly the number of shoots (Figure S2a), and R1, R2, R3, and Ch2 treatments were the most essential in case of root length (Figure S3a).

The biomass is mainly formed by stems when $M . \times$ giganteus is harvested [59]. Therefore, the enhancement of biomass is among the targeted goals when the crop is grown on different marginal lands, including post-military areas [60]. This goal may be achieved by applying varied agricultural practices, including treatment by PGRs [36]. The results (Table 5) showed that the dry biomass value is primarily dependent on the length of stems (Figure 1) and the variety of PGR applied (Figure 2) $(p<0.001)$

Table 5. Evaluation of the effect of the research factors, PGRs, soil type, and year of vegetation, on dry biomass yield following M-GLM procedures $\left(R_{a d j}{ }^{2}=0.74, F=8.9, p<0.001\right)$.

\begin{tabular}{ccc}
\hline Effect & F-Ratio & $p$-Level \\
\hline Year & 0.01 & 0.91 \\
Soil & 0.35 & 0.56 \\
PGR & 4.26 & $<0.001$ \\
Year $\times$ Soil & 0.74 & 0.39 \\
Year $\times$ PGR & 2.25 & 0.03 \\
Soil $\times$ PGR & 1.58 & 0.15 \\
Year $\times$ Soil x PGR & 1.34 & 0.24 \\
Length of stems & 18.44 & $<0.001$ \\
Length of roots & 0.08 & 0.77 \\
Number of shoots & 0.16 & 0.69 \\
Number of stems & 0.00 & 0.97
\end{tabular}

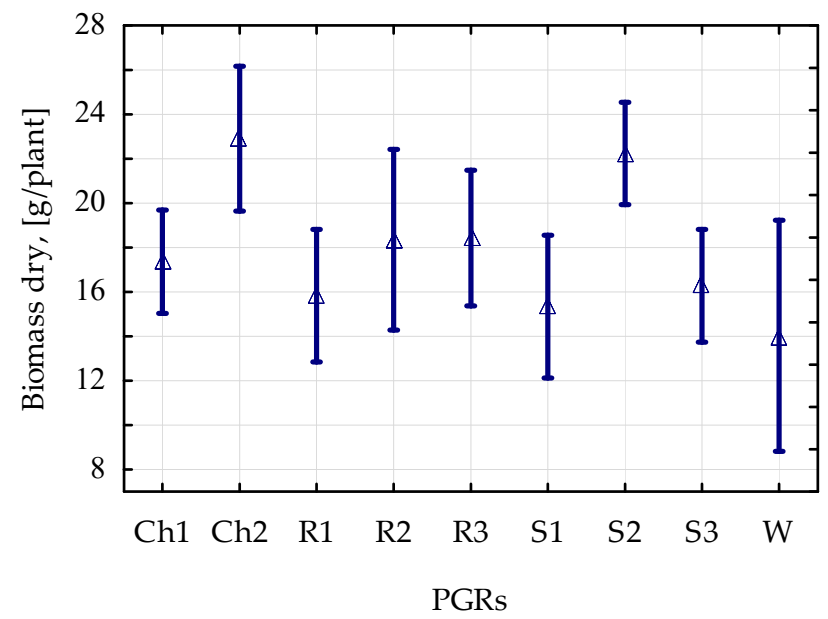

Figure 2. Impact of various PGR treatments on $M . \times$ giganteus dry biomass. Triangles show least square means. Vertical bars denote 0.95 confidence intervals.

In this regard, the gradation of factors influenced stem length and the determination of the extent to which these results depended on PGR treatment is essential for enhancing M. $\times$ giganteus biomass. The results shown in Figure 1 illustrate that in the first year of vegetation in Soil I the impact of PGRs had the following order: Ch2 > Ch1 > R1 > S2; for another treatment, the effect was neglected and close to the treatment with water (control). In the second year of vegetation, the order of PGR impact was changed for Soil I: S2 > Ch2 $>\mathrm{R} 2 \geq \mathrm{R} 3$; S1 > Ch1, S3; for other treatments, the effect was neglected and close to the control. These results showed that, while for the first year of vegetation the influence of Charkor on increased root growth was the main factor related to enhancing biomass values (Figure 2), for the second year, the treatment of aboveground biomass competed with the 
treatment of rhizomes and resulted in longer stem length under this treatment. For the first year of vegetation in Soil II, the impact of PGRs had the following order: Ch2, Ch1 > R1, S2; for other treatments, the effect was neglected and close to the control treatment. In the case of Soil II, the effect of treatment by Charkor, which influences root system development [9], was the main factor for the first year of growing, similar to Soil I. For the second year, the influence of PGRs had the following order: Ch2 $\geq \mathrm{Ch} 1>$ S2, S1; for other treatments, the influence of PGRs was the same as for the control. These results highlighted that for the second year the influence of PGRs in the better quality Soil II was altered compared to the influence in the poorer quality soil of Soil I. For both years, the prevailing impact of Charkor in the better quality Soil II revealed that this particular PGR could be recommended for increasing stem length (and biomass value) when the crop is produced in good quality soil. When the soil quality is worse (Soil I), combined treatment with the other PGRs studied, Stimpo and Regoplant, gives almost the same effect as Charkor for increasing stem length (biomass value).

PGR treatment impacts on dry biomass yield showed (Figure 2) that the most potent influence was observed for Ch2; the order of impact was the following: Ch2 followed by S2, R2, R2, Ch1; for another treatment, the effect was neglected and almost the same as for control. This observation is correlated with the impact of PGR treatment on length and is in line with the results of [9], which showed that Charkor is an effective substance for enhancing $M . \times$ giganteus development due to stimulation of the root system, which is among the main factors in plant development [64].

The stimulating effects of two factors (Year and PGR) were essential for the second year of vegetation and noted for almost all PGR treatments besides Ch1, S1, and S3. Comparison of $\mathrm{Ch} 1$ and $\mathrm{Ch} 2$ showed that $\mathrm{Ch} 2$ had a greater stimulating influence on the effects of the two factors.

\section{Conclusions}

The impact of three studied factors, PGRs, soil type, and year of vegetation, were evaluated for two vegetation seasons during the growth of the second-generation energy crop $M . \times$ giganteus in marginal post-military soils supported by the treatment of rhizomes with PGRs. The M-GLM statistical approach showed that these factors influenced plant bioparameters (stems, shoot and root lengths) and dry biomass yield. As a result, increased plant height and a larger amount of $M . \times$ giganteus biomass were ultimately achieved. However, stimulation of other aspects of individual plant growth can increase competition between individuals, which may not increase the proportional growth of biomass and its energy output.

The results of two years of production of $M . \times$ giganteus stimulated by various PGR treatments emphasized that treatment by Charkor in higher concentrations positively influenced biological parameters and dry biomass value, and the effect was much more vigorous for the second vegetation year. Therefore, this PGR can be recommended for practical application on $M . \times$ giganteus plantations to enhance plant development and biomass production. However, other studied PGR treatments were not as effective in terms of biomass production despite certain combinations of treatments showing satisfactory results.

To the best of our knowledge, the results reported here represent the first systematic study comparing the influence of the common PGRs Charkor, Regoplant, and Stimpo on the production of $M . \times$ giganteus over two years in lab conditions. The results obtained permitted the conclusion that when a crop is grown at a field scale on post-military marginal soil, only Charkor may be utilized; in particular, the effect of its positive influence has to be evident with years of growing. Two other researched PGRs (Stimpo and Regoplant), despite earlier reported positive influence on the development of common crops (corn and barley) [7-10,55], appeared not to be so effective in the case of the development of $M . \times$ giganteus and cannot be recommended for broad utilization in field conditions when economics is among the main decision-making factors. Future research should focus 
on verifying the field-scale recommendations for $M . \times$ giganteus plantations established on post-military land and on comparing the results of lab and field-scale experiments.

Supplementary Materials: The following supporting information can be downloaded at: https:// www.mdpi.com/article/10.3390/app12020881/s1. Table S1. Descriptive statistics of morphometric traits of Miscanthus; Figure S1. The effect of PGRs on number of steams (a) depending of soil's type (b). Squares and circles show least square means. Vertical bars denote 0.95 confidence intervals; Figure S2. The effect of PGRs on shoot number (a) depending of soil's type (b). Squares and circles show least square means. Vertical bars denote 0.95 confidence intervals; Figure S3. The effect of PGRs on root length (a) depending of soil's type (b). Squares and circles show least square means. Vertical bars denote 0.95 confidence intervals; Figure S4. The effect of PGRs on stem's length (a) depending of soil's type (b). Squares and circles show least square means. Vertical bars denote 0.95 confidence intervals.

Author Contributions: Conceptualization, V.P. and T.S.; methodology, V.P., T.S. and A.M.; software, O.Z.; validation, A.M., V.S. and M.S.; formal analysis, investigation, V.P., T.S. and P.S.; resources, A.M. and P.S.; data curation, A.M., V.S. and M.S.; writing-original draft preparation, V.P. and T.S.; writing-review and editing, V.P., T.S. and O.Z.; visualization, O.Z.; supervision, V.P and T.S.; project administration, V.P. and T.S.; funding acquisition, V.P. All authors read and agreed to the published version of the manuscript.

Funding: This research was funded by the CORNET Czech-German project "MiscanValue" and the NATO Science for Peace and Security Programmer, Multiyear Project G4687.

Institutional Review Board Statement: Not applicable.

Informed Consent Statement: Not applicable.

Acknowledgments: We would like to thank Oleksandr Ponomarenko, Ukraine (posthumously) for granting studied samples of PGRs and Ethan Nicolas Duong, Canada for editing the reviewed manuscript. The research was performed using the equipment of Laboratory of Advanced Technologies, Creation and Physico-Chemical Analysis of a New Substances and Functional Materials, Lviv Polytechnic National University, Ukraine (https:/ / lpnu.ua/ckkno, accessed on 10 November 2021).

Conflicts of Interest: The authors declare no conflict of interest.

\section{References}

1. du Jardin, P. Plant biostimulants: Definition, concept, main categories and regulation. Sci. Hortic. 2015, 196, 3-14. [CrossRef]

2. Bálványos, I.; Kursinszki, L.; Szõke, É. The effect of plant growth regulators on biomass formation and lobeline production of Lobelia inflata L. hairy root cultures. Plant Growth Regul. 2001, 34, 339-345. [CrossRef]

3. Jeong, S.; Moon, H.S.; Shin, D.; Nam, K. Survival of introduced phosphate-solubilizing bacteria (PSB) and their impact on microbial community structure during the phytoextraction of Cd-contaminated soil. J. Hazard. Mater. 2013, 263, 441-449. [CrossRef]

4. Kang, Y.; Lee, S.-H.; Lee, J. Development of a selective medium for the fungal pathogen cylindrocarpon destructans using radicicol. Plant Pathol. J. 2014, 30, 432-436. [CrossRef]

5. Sharma, S.; Kaur, M. Plant hormones synthesized by microorganisms and their role in biofertilizer-A review article. Int. J. Adv. Res. 2017, 5, 1753-1766. [CrossRef]

6. Ponomarenko, S.P.; Terek, O.I.; Grytsaenko, Z.M.; Babayants, O.V.; Moiseeva, T.V.; Wenxiu, H.; Eakin, D. Bioregulation of growth and development of plants: Plant growth regulators in crop science. In Bioregulyatsiya Mikrobnorastitel'nykh System [Bioregulation of Microbial-Plant Systems]; Ponomarenko, S.P., Iutynska, H.O., Eds.; Nichlava: Kyiv, Ukraine, 2010; pp. 251-291. (In Russian)

7. Tsygankova, V.A.; Stefanovska, T.R.; Galkin, A.P.; Ponomarenko, S.P.; Blume, Y.B. Inducing effect of PGRs on small regulatory si/miRNA in resistance to sugar beet cyst nematode. Commun. Agric. Appl. Biol. Sci. 2012, 77, 779-787.

8. Tsygankova, V.A.; Andrusevych, Y.V.; Babayants, Y.V.; Ponomarenko, S.P.; Medkow, A.I.; Galkin, A.P. Stimulation of plant immune protection against pathogenic fungi, pests and nematodes with growth regulators. Physiol. Biochem. Cultiv. Plants 2013, 45, 138-147.

9. Ponomarenko, S.P.; Stefanovska, T.R.; Medkow, A.I.; Kapriy, M. Bioregulators of plant development in growing biofuel crops. In Proceedings of the 17th International Scientific Conference Sakharov Readings: Enviornmental Problems of the XXI Century, II, Minsk, Belarus, 18-19 May 2017; pp. 40-42.

10. Blyuss, K.B.; Fatehi, F.; Tsygankova, V.A.; Biliavska, L.O.; Iutynska, G.O.; Yemets, A.I.; Blume, Y.B. RNAi-based biocontrol of wheat nematodes using natural poly-component biostimulants. Front. Plant Sci. 2019, 10, 483. [CrossRef] 
11. Kvak, V.; Stefanovska, T.; Pidlisnyuk, V.; Alasmary, Z.; Kharytonov, M. The long-term assessment of Miscanthus $\times$ gigantheus cultivation in the forest-steppe zone of Ukraine. INMATEH Agric. Eng. 2018, 54, 113-121.

12. Roik, M.; Sinchenko, V.; Purkin, V.; Kvak, V.; Humentik, M. Miscanthus in Ukraine; FOP Yamchinskiy Press: Kyiv, Ukraine, 2019; ISBN 978-617-7804-11-5.

13. Geletukha, G.G.; Zheliezna, T.A.; Tryboi, O.V.; Bashtovyi, A.I. Analysis of criteria for the sustainable development of bioenergy. Ind. Heat Eng. 2016, 38, 47-55. [CrossRef]

14. Vorobey, V.; Melekh, Y.; Gudz, N. Using of Biomass of the Energy Crops in the Northern Regions of Ukraine. Analytical Research Review; Agency for Economical Development PPV Knowledge Networks: Lviv, Ukraine, 2018.

15. Pidlisnyuk, V.; Shapoval, P.; Zgorelec, Ž.; Stefanovska, T.; Zhukov, O. Multiyear phytoremediation and dynamic of foliar metal(loid)s concentration during application of Miscanthus $\times$ giganteus Greef et Deu to polluted soil from Bakar, Croatia. Environ. Sci. Pollut. Res. 2020, 27, 31446-31457. [CrossRef]

16. Malinská, H.; Pidlisnyuk, V.; Nebeská, D.; Erol, A.; Medžová, A.; Trögl, J. Physiological response of Miscanthus x giganteus to plant growth regulators in nutritionally poor soil. Plants 2020, 9, 194. [CrossRef]

17. Pidlisnyuk, V.; Herts, A.; Khomenchuk, V.; Mamirova, A.; Kononchuk, O.; Ust'ak, S. Dynamic of morphological and physiological parameters and variation of soil characteristics during Miscanthus $\times$ giganteus cultivation in the diesel-contaminated land Agronomy 2021, 11, 798. [CrossRef]

18. Lewandowski, I.; Clifton-Brown, J.; Kiesel, A.; Hastings, A.; Iqbal, Y. Miscanthus. In Perennial Grasses for Bioenergy and Bioproducts; Alexopoulou, E., Ed.; Elsevier Inc. Academic Press: Cambridge, MA, USA, 2018; pp. 35-59, ISBN 978-0-12-812900-5.

19. Ben Fradj, N.; Rozakis, S.; Borzęcka, M.; Matyka, M. Miscanthus in the European bio-economy: A network analysis. Ind. Crops Prod. 2020, 148, 112281. [CrossRef]

20. Zhao, J.; Wang, D.; Pidlisnyuk, V.; Erickson, L.E. Miscanthus biomass for alternative energy production. In Phytotechnology with Biomass Production; Erickson, L.E., Pidlisnyuk, V., Eds.; CRC Press: Boca Raton, FL, USA, 2021; pp. 177-200, ISBN 978-0-367-52280-3.

21. Jayaraman, K.; Gökalp, I. Pyrolysis, combustion and gasification characteristics of miscanthus and sewage sludge. Energy Convers. Manag. 2015, 89, 83-91. [CrossRef]

22. Pidlisnyuk, V.; Newton, R.; Mamirova, A. Miscanthus biochar value chain-A review. J. Environ. Manag. 2021, $290,112611$. [CrossRef] [PubMed]

23. Kharytonov, M.; Pidlisnyuk, V.; Stefanovska, T.; Babenko, M.; Martynova, N.; Rula, I. The estimation of Miscanthus $\times$ giganteus adaptive potential for cultivation on the mining and post-mining lands in Ukraine. Environ. Sci. Pollut. Res. 2019, 26, 2974-2986. [CrossRef]

24. Żołnowski, A.C.; Wyszkowski, M.; Rolka, E.; Sawicka, M. Mineral materials as a neutralizing agent used on soil contaminated with copper. Materials 2021, 14, 6830. [CrossRef]

25. Fei, H.; Crouse, M.; Papadopoulos, Y.A.; Vessey, J.K. Improving biomass yield of giant Miscanthus by application of beneficial soil microbes and a plant biostimulant. Can. J. Plant Sci. 2020, 100, 29-39. [CrossRef]

26. Alasmary, Z.; Todd, T.; Hettiarachchi, G.M.; Stefanovska, T.; Pidlisnyuk, V.; Roozeboom, K.; Erickson, L.; Davis, L.; Zhukov, O. Effect of soil treatments and amendments on the nematode community under Miscanthus growing in a lead contaminated military site. Agronomy 2020, 10, 1727. [CrossRef]

27. Zinchenko, O. Evaluation of the influence of plant growth regulators on theintensity of photosynthesis, survival, morphological parameters of Miscanthus $\times$ giganteus. Sci. Work. Inst. Bioenergy Crop. Sugar Beets 2013, 19, 47-51.

28. Kim, H.S.; Zhang, G.; Juvik, J.A.; Widholm, J.M. Miscanthus $\times$ giganteus plant regeneration: Effect of callus types, ages and culture methods on regeneration competence. GCB Bioenergy 2010, 2, 192-200. [CrossRef]

29. Guo, H.P.; Shao, R.X.; Hong, C.T.; Hu, H.K.; Zheng, B.S.; Zhang, Q.X. Rapid in vitro propagation of bioenergy crop Miscanthus sacchariflorus. Appl. Mech. Mater. 2012, 260-261, 181-186. [CrossRef]

30. Ślusarkiewicz-Jarzina, A.; Ponitka, A.; Cerazy-Waliszewska, J.; Wojciechowicz, M.K.; Sobańska, K.; Jeżowski, S.; Pniewski, T Effective and simple in vitro regeneration system of Miscanthus sinensis, $M . \times$ giganteus and M. sacchariflorus for planting and biotechnology purposes. Biomass Bioenergy 2017, 107, 219-226. [CrossRef]

31. Padhye, S.R.; Groninger, J.K. Influence of benzyladenine, trinexapac-ethyl, or uniconazole applications on height and tillering of six ornamental grasses. Horttechnology 2009, 19, 737-742. [CrossRef]

32. Katelevskij, V.; Gumentyk, M.; Kharytonov, M. Plant growth stimulants influence on Miscanthus $\times$ giganteus biomass indexes in forest-Steppe zone of Ukraine. Sci. Pap. Ser. A Agron. 2020, LXIII, 341-345.

33. Helios, W.; Kotecki, A. Wpływ Terminu I Miejsca Pobierania Sadzonek Oraz Regulatorów Wzrostu Na Zdolność Regeneracyjna Jedno-I Dwuwęzłowych Pędów Miscanthus $\times$ Giganteus (Greef Etdeu). Zesz. Nauk. Uniw. Przyr. We Wrocławiu Rol. 2014, 111, 41-50.

34. Schmidt, C.S.; Mrnka, L.; Frantík, T.; Motyka, V.; Dobrev, P.I.; Vosátka, M. Combined effects of fungal inoculants and the cytokinin-like growth regulator thidiazuron on growth, phytohormone contents and endophytic root fungi in Miscanthus $\times$ giganteus. Plant Physiol. Biochem. 2017, 120, 120-131. [CrossRef]

35. Podan, I.I.; Dzhura, N.M. Influence of oil pollution and humates on growth of miscanthus plants. Ecol. Sci. 2019, 2, 182-186. [CrossRef] 
36. Nebeská, D.; Pidlisnyuk, V.; Stefanovska, T.; Trögl, J.; Shapoval, P.; Popelka, J.; Cerný, J.; Medkow, A.; Kvak, V.; Malinská, H. Impact of plant growth regulators and soil properties on Miscanthus $\times$ giganteus biomass parameters and uptake of metals in military soils. Rev. Environ. Health 2019, 34, 283-291. [CrossRef]

37. Winkler, B.; Mangold, A.; von Cossel, M.; Clifton-Brown, J.; Pogrzeba, M.; Lewandowski, I.; Iqbal, Y.; Kiesel, A. Implementing miscanthus into farming systems: A review of agronomic practices, capital and labour demand. Renew. Sustain. Energy Rev. 2020, 132, 110053. [CrossRef]

38. Gerwin, W.; Repmann, F.; Galatsidas, S.; Vlachaki, D.; Gounaris, N.; Baumgarten, W.; Volkmann, C.; Keramitzis, D.; Kiourtsis, F.; Freese, D. Assessment and quantification of marginal lands for biomass production in Europe using soil-quality indicators. Soil 2018, 4, 267-290. [CrossRef]

39. DSTU4287:2004 Soil Quality; Sampling. State Enterprice “Ukrainian Research and Training Center of Standardization. Certification and Quality, UkrNDNC": Kyiv, Ukraine, 2005; p. 9.

40. DSTU:ISO:11464:2007 Soil Quality; Pretreatment of Samples for Physicochemical Analysis. DP “UkrNDNC": Kyiv, Ukraine, 2007; p. 12.

41. DSTU:ISO:10390:2001 Soil Quality; Determination of pH. State Enterprice “Ukrainian Research and Training Center of Standardization. Certification and Quality", UkrNDNC: Kyiv, Ukraine, 2002; p. 10.

42. DSTU:4115:2002 Soils; Determination of Mobile Phosphorus and Potassium Compounds by the Modified Chirikov's Method. State Enterprice "Ukrainian Research and Training Center of Standardization. Certification and Quality", UkrNDNC: Kyiv, Ukraine, 2003; p. 12.

43. DSTU:7861:2015 Soil Quality; Determination of Exchanges Calcium, Magnesium, Sodium and Potassium in Soil According to Shollenberger in NSC ISSAR Named after Sokolovsky Modification. State Enterprice "Ukrainian Research and Training Center of Standardization. Certification and Quality", UkrNDNC: Kyiv, Ukraine, 2016; p. 12.

44. DSTU:7863-2015 Soil Quality; Determination of Alkalinehydrolysed Nitrogen by the Cornfield Method. State Enterprice "Ukrainian Research and Training Center of Standardization. Certification and Quality", UkrNDNC: Kyiv, Ukraine, 2015; p. 12.

45. DSTU:8347-2015 Soil Quality; Determination of Available Sulphur in Modification of NSC IGA Name Sokolovsky. State Enterprice "Ukrainian Research and Training Center of Standardization. Certification and Quality", UkrNDNC: Kyiv, Ukraine, 2015 ; p. 12.

46. DSTU:7632-2014 Soils. Method for Determination of Organic Matter; State Enterprice "Ukrainian Research and Training Center of Standardization. Certification and Quality", UkrNDNC: Kyiv, Ukraine, 2014; p. 15.

47. DSTU:4730:2007 Soil Quality; The Soil Granulometric Composition Analysis by Pipette Method in Modification of N.A. Kachinsly. State Enterprice "Ukrainian Research and Training Center of Standardization. Certification and Quality", UkrNDNC: Kyiv, Ukraine, 2008; p. 14.

48. Hodzic, D.; Hodzic, A.; Bajramovic, E. Latin square experiment design in R. IOP Conf. Ser. Mater. Sci. Eng. 2019, 477, 012019. [CrossRef]

49. GOST 12.1.007:76 Occupational safety standards system; Noxious Substances. Classification and General Safety Requirements. Standart is in Force since 1 January 1977. Interstate Council for Standardization, Metrology and Certification (ISC): Moscow, Russia, 1977.

50. Zinchenko, O.; Zinchenko, V.; Ponomarenko, S. Environmental aspects of the cultivation of giant miscanthus, potato and oat. In Phytotechnology woth Biomass Production for Revitalization of Land Contamoinated or Damaged as a Results of the Military Activities; NULES: Kyiv, Ukraine, 2016; pp. 102-105.

51. Technical conditions of Ukraine 20.2-31168762-005:2012; Plant Grow Regulator "Stimpo". CSM: Kyiv, Ukraine, 2020 ; 39.

52. Technical conditions of Ukraine 20.2-31168762-006:2012; Plant Grow Regulator "Regoplant". CSM: Kyiv, Ukraine, $2014 ; 39$.

53. Technical conditions of Ukraine 24.2-03563790-041-2001; Plant Grow Regulator “Charkor”. CSM: Kyiv, Ukraine, $2016 ; 25$.

54. Certificate No. 21-1652-01-01 2023-01-31; Standard for input Production for Use in Organic Agriculture and Processing (Based on the Equivalent eu Organic Production \& Processing Standard for Third Countries). Agrobiotech: Kyiv, Ukraine, 2021.

55. Ponomarenko, S.P.; Grizaenko, Z.M.; Babayantz, O.B. Plant Growth Regulators. Recommendations for Utilization; Agrobiotech: Kyiv, Ukraine, 2015

56. Statistics; Version 13; Data Analysis Software System; TIBCO Software Inc.: Palo Alto, CA, USA, 2021; Available online: http:/ /Statistica.io (accessed on 1 September 2021).

57. Leonard, M.; Pisani-Ferry, J.; Shapiro, J.; Tagliapietra, S.; Wolff, G. The geopolitics of the European Green Deal. Policy Contrib. Bruegel 2021, 4, 1-23. Available online: https:/ / www.bruegel.org/2021/02/the-geopolitics-of-the-european-green-deal (accessed on 10 January 2022). [CrossRef]

58. Briens, C.; Piskorz, J.; Berruti, F. Biomass valorization for fuel and chemicals production-A review. Int. J. Chem. React. Eng. 2008, 6. [CrossRef]

59. Lewandowski, I.; Clifton-Brown, J.; Trindade, L.M.; van der Linden, G.C.; Schwarz, K.-U.; Müller-Sämann, K.; Anisimov, A.; Chen, C.-L.; Dolstra, O.; Donnison, I.S.; et al. Progress on optimizing miscanthus biomass production for the European bioeconomy: Results of the EU FP7 project OPTIMISC. Front. Plant Sci. 2016, 7, 159-167. [CrossRef]

60. Alasmary, Z.; Hettiarachchi, G.M.; Roozenboom, K.; Davis, L.A.; Erickson, L.E.; Pidlisnyuk, V.; Stefanovska, T.; Trogl, J. Phytostabilization of a contaminated military site using Miscanthus and soil amendments. J. Environ. Qual. 2021, 50, 1220-1232. [CrossRef] 
61. Mamirova, A.; Pidlisnyuk, V.; Amirbekov, A.; Ševců, A.; Nurzhanova, A. Phytoremediation potential of Miscanthus sinensis And. in organochlorine pesticides contaminated soil amended by Tween 20 and Activated carbon. Environ. Sci. Pollut. Res. 2021, 28, 16092-16106. [CrossRef]

62. Antonkiewicz, J.; Kołodziej, B.; Bielińska, E.J.; Popławska, A. The possibility of using sewage sludge for energy crop cultivation exemplified by reed canary grass and giant miscanthus. Soil Sci. Annu. 2019, 70, 21-33. [CrossRef]

63. Pranaw, K.; Pidlisnyuk, V.; Trogl, J.; Malinska, H. Bioprospecting of a novel Plant Growth-Promoting Bacterium Bacillus Altitudinis KP-14 for enhancing Miscanthusxgignateus growth in metals contaminated soil. Biology 2020, 9, 305. [CrossRef] [PubMed]

64. Kvak, V. Optimization of Elements of Technology for Production Miscanthus for Energy Fuel in the Western Part of Ukrainian Forest-Step. Ph.D. Thesis, Institute of Bioenergy Crops and Sugar Beets, Kyiv, Ukraine, 24 March 2014.

65. Tikhonenko, D.; Gorin, M.; Laktionov, M.; Kanivec, V.; Medvedev, V.; Baluk, S.; Buligin, S.; Truskaveckii, R.; Kanash, O.; Degtyar'ov, V. Soil Science; Tikhonenko, D., Ed.; Higher Education: Kyiv, Ukraine, 2005; ISBN 966-8081-37-4.

66. GOST:12248.6-2020 Interstate Standard. Soils; Methods for Determination of Swelling and Shrinking Characteristics. Interstate Council for Standardization, Metrology and Certification (ISC): Moscow, Russia, 2020; 12.

67. Jones, L.; Banks, V.; Jefferson, I. Chapter 8 Swelling and shrinking soils. Geol. Soc. Lond. Eng. Geol. Spec. Publ. 2020, 29, $223-242$. [CrossRef] 